\title{
Debt crisis threatens UK science
}

\section{As Britain's researchers face fierce budget cuts, Nature finds out how labs are preparing for hard times.}

Gabriel Aeppli has spent decades probing the nanostructure of materials, but today it is financial woes that are on his mind.

As director of the London Centre for Nanotechnology, Aeppli is responsible for making sure the laboratory continues to bring in funding at the current level of about $£ 10$ million (US\$16 million) each year. "I am worried, obviously," he says in his soft American accent. "I worry all the time."

Like many scientists in Britain, Aeppli has grown more anxious in recent months. Faced with a rapidly growing debt that stood at $£ 800$ billion in March 2009, according to government figures, the United Kingdom is poised to make deep cuts in public spending. It is probably not alone: governments across the globe have run up high deficits in recent years (see 'Debt threat'), and economists expect that many will soon be faced with the stark choice of raising taxes or lowering budgets.

In Britain, policy experts say that funding for science will probably decline no matter who takes power in this year's general election, which must be held by 3 June. The cuts will mark the first time in more than a decade that research spending has not grown.

It's a familiar worry for an older generation of British scientists who can still remember when a conservative government led by Margaret Thatcher slashed research spending in the 1980s. Denis Noble, a cardiologist at the University of Oxford, recalls serving on grant committees that had to choose just one out of dozens of applications. "The meetings became pointless really," he says. "At that level of cut you really can't cope."

But British science has flourished under a science-friendly Labour government. Since the late 1990s, UK research has enjoyed strong growth in funding (see 'The British science boom'). The money has supported endeavours such as the Centre for Nanotechnology, a joint venture between Imperial College London and University College London (UCL). The centre was kicked off in 2002 with $£ 14$ million from a government grant and the Wellcome Trust, Britain's largest charity, which funds biomedical research.

The commitment helped to lure Aeppli, then a senior scientist at the research campus of Japanese electronics manufacturer NEC in Princeton, New Jersey, to head the centre. At the time, other countries were making larger sums of money available for nanotechnology,

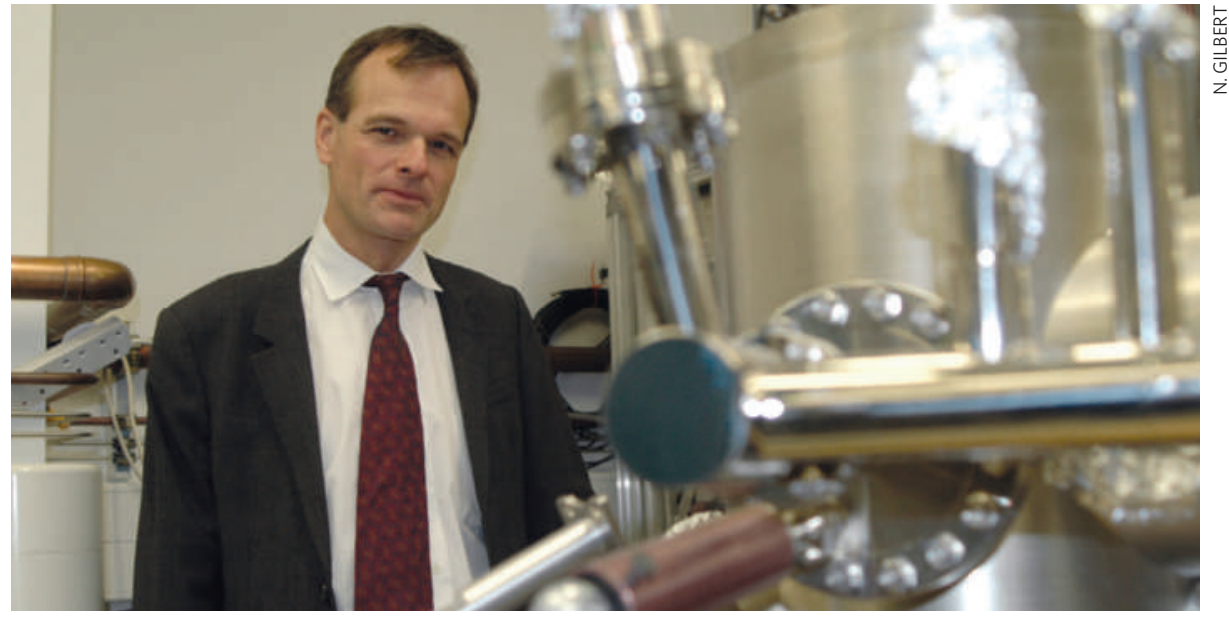

Gabriel Aeppli hopes to secure funding by focusing research on areas of economic importance.

but Aeppli says he was promised a great deal of independence in setting up his new lab. "That was quite unique," he recalls. "I was just handed [the money] and told to go figure it out." When the centre opened in 2006, it had drawn in additional funding and constructed an eightstorey laboratory in central London. Today the lab houses state-of-the-art scanning tunnelling microscopes and fabrication facilities, which are used to study a wide variety of basic and applied problems in materials science.

The government could afford to finance such projects because the British economy was booming. Throughout the late 1990s and early 2000 s, a strong property market and financial sector swelled the treasury's coffers. But the

\section{DEBT THREAT}

The United Kingdom's national deficit is greater than those of other leading science-producing countries.

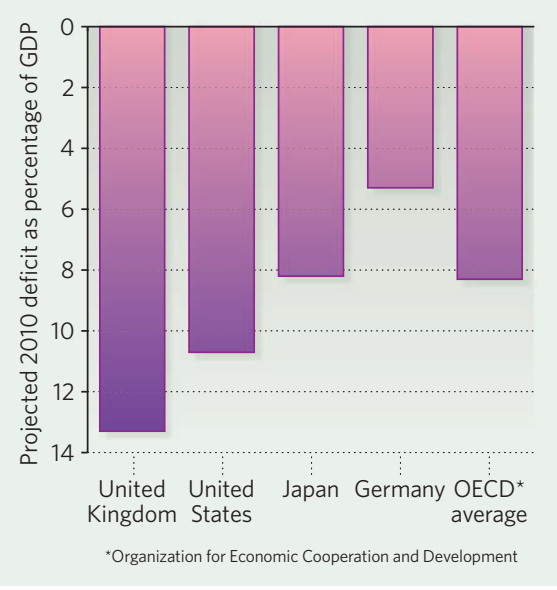

collapse of those areas in 2007 and 2008 has left the UK government short of revenue at a time when it needs it the most. The government has run up a heavy deficit bailing out banks and stimulating consumer spending, and public-spending cuts are the only way to balance its books.

\section{A global problem}

Britain's predicament is hardly unique. The United States, Japan and several European nations, including Ireland and Greece, have seen deficits rise sharply as they attempt to jump-start their economies. In December 2009, the newly elected Japanese government proposed cutting back or closing down several large science projects as part of a ¥3-trillion (US\$33.7-billion) budget-trimming process (see Nature 462, 835; 2009), sparking outrage in the scientific community - the government subsequently revoked most of the proposed cuts.

In the United States, a US\$787-billion stimulus package has boosted research in the short term, but few expect to see further increases in this year's budget, and spending will drop after the stimulus runs out. Moreover, falling state budgets and university endowments are taking a heavy toll, says Matt Owens, an associate vicepresident for federal relations at the Association of American Universities, a university advocacy group in Washington DC. "At US research universities, they're looking at significant budget shortfalls in the near future," he warns.

The 'near future' may yet be a year or two away for American scientists. But in Britain, 
$\stackrel{\sim}{\infty}$ cuts will bite within months. The current

ư Labour government has delayed drawing up its next three-year budget until after this summer's election, but a pre-budget report released on 9 December 2009 called for "efficiency savings" in several sectors, including research. In late December, Peter Mandelson, the UK minister for business, innovation and skills, warned that universities would lose $£ 950$ million in government support between 2010 and 2013 - but he emphasized that the reduction was less than $5 \%$ of the total expected over that period.

Many universities, including leading research institutions such as Imperial and UCL, are already tightening their belts in preparation. Between July and September 2009, Imperial cut 48 jobs from its faculty of medicine; roughly half were academic posts. And on 14 January, UCL announced that it hopes to trim $£ 3$ million $-6 \%$ of staff costs - from its faculty of life sciences. Because much of Britain's research funding is distributed according to a formula based on a university's size and quality, smaller and less-research-intensive universities are expected to be hit harder.

Research councils - the government funding bodies that provide some $\mathfrak{£} 3$ billion annually in grants - are also likely to feel the pinch. For the past decade, research-council funding has increased steadily. But at a recent debate on science in central London, none of the research ministers of the nation's three major political parties could promise that funding would continue at present levels.

One council in particular is already acutely aware of the recession. Since its creation in 2007, the Science and Technology Facilities Council (STFC), which distributes most of Britain's physics and astronomy grants, has been chronically short of cash. Battered by a falling pound, which raises the cost of overseas projects, and a flat budget that has never met its needs, the STFC is facing a $£ 40$-million spending deficit, which has forced it to make cuts to research grants. The cuts have also caused the council to rethink its international commitments: it is now planning to withdraw from the Gemini project, which operates twin telescopes in Chile and Hawaii (see Nature 462, 396; 2009).

John Womersley, the STFC's director for scientific programmes, sees little relief in sight. The only sure thing, Womersley says, is that after the election ministers will be fighting over spending on big government items such as defence, health and education. "There's likely to be a tough scramble over how the budget will be allocated," he says. "The question is: is science special?” If research funding is to be
THE BRITISH SCIENCE BOOM

UK government base funding for R\&D

has grown steadily over the past decade.

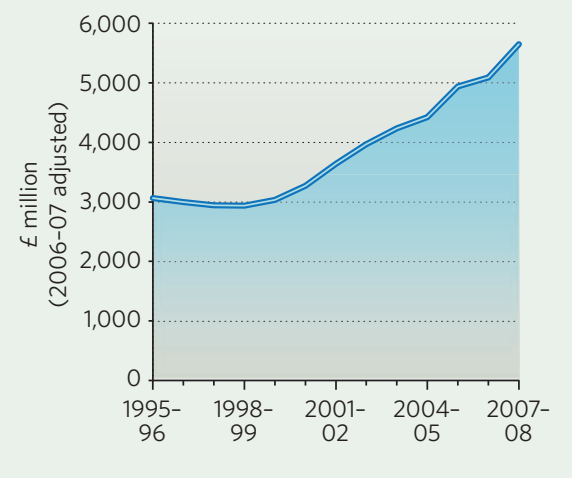

protected, Womersley believes, scientists will have to present a unified case to all political parties. Some politicians are already talking about cutting back on fundamental research that lacks an obvious application, he says. It will be up to scientists to show the relevance of their work, either by providing a potential link to an area of economic activity or by showing its educational benefits.

This emphasis on the broader impact of research is also expected to be a key part of the Research Excellence Framework, a system that will be used to assess university research quality to determine funding levels (see Nature 463, $291 ; 2010)$.

But some researchers are uneasy about making such justifications. Too much emphasis is already being placed on publication rates and economic benefit, says Robert May, a zoologist at the University of Oxford and a former government chief scientific adviser. "I don't think Watson and Crick could have existed under the current regime," he adds.

Back in London, Aeppli is preparing the nanotechnolahead. He is encouraging his staff to bring in grants from non-governmental sources, including charities and the European Union. $\mathrm{He}$ is also steering the centre's research agenda towards issues such as climate and health, areas he believes the government will fund to help improve the economy in the long term.

Balancing those projects against fundamental science will be tricky, he admits, but he believes the centre will survive and could even prosper in the difficult years ahead. "We've been planning for this downturn for a while," he says. "I think that if we're working in the right areas, there will be growth."

Geoff Brumfiel

See Editorial, page 402.

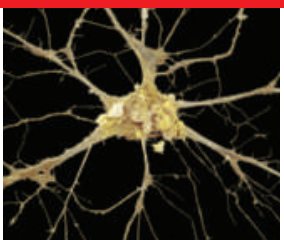

UNLIKELY PROTECTOR Prion proteins that can cause CJD have a vital role in the nervous system. go.nature.com/zK5sEq
Stem-cell line given the nod

US stem-cell researchers had reason to celebrate last week. The uncertain fate of human embryonic stem-cell lines from the George W. Bush era became a bit clearer as the National Institutes of Health (NIH) moved to approve one of the lines most widely used during the past decade.

Last July, after President Barack Obama overturned his predecessor's restrictive stem-cell policy, the NIH announced new rules on using human embryonic stem cells in federally funded research. Since then, the number of available lines on the government's stem-cell registry has already reached 42 - double that of Bush's day - but none of the 21 lines approved under Bush has yet received the go-ahead under the new rules.

To become eligible for funding, cell lines have to be reviewed on a caseby-case basis to ensure that they were derived from excess embryos used for in vitro fertilization and were donated voluntarily, without inducement.

Notably, researchers hoping to apply for grants using two Bush-era lines from the WiCell Research Institute in Madison, Wisconsin $-\mathrm{H} 1$ and $\mathrm{H} 9$, which account for some $70 \%$ of stem-cell shipments from the National Stem Cell Bank — had been left in limbo for the past six months.

"Once we learned about not being able to use the cell lines, there was a lot of uncertainty about what to do," says Thomas Zwaka, a biologist at Baylor College of Medicine in Houston, Texas.

On 22 January, the advisory committee to NIH director Francis Collins told him to give $\mathrm{H} 1$ the thumbs up, but said the line's usage should be restricted according to the consent forms signed by the embryo donors in 1998. The NIH generally allows stem cells to be combined with the cells of non-primate animals, but donors of the $\mathrm{H} 1$ cells signed a form that indicated that cells would not be mixed with those of any other embryo, human or animal. Collins says the general policy for all lines will be to post the exact language of consent forms on the stem-cell registry.

Janet Kelly, a spokeswoman for WiCell, says the institute plans to submit an application for $\mathrm{H} 9$, along with three other lines, as soon as possible.

Brendan Borrell 